Goldschmidt 2021 Abstract

https://doi.org/10.7185/gold2021.4454

\section{Molybdenum Isotope Systematics in the High-P/T Schistes Lustrés and at Lago di Cignana: Investigation of Partitioning and Isotopic Fractionation During Subduction Zone Metamorphism}

SAMUEL J MARSHALL ${ }^{1}$, RICHARD M. GASCHNIG ${ }^{2}$ CASSIDY J. STEGNER ${ }^{2}$, SHELBY T. RADER ${ }^{3}$ AND GRAY E. BEBOUT ${ }^{4}$

${ }^{1}$ University of Massachusetts Lowell

${ }^{2}$ University of Massachusetts - Lowell

${ }^{3}$ Indiana University

${ }^{4}$ Lehigh University

Presenting Author: Samuel_Marshall@student.uml.edu

In recent years, new non-traditional stable isotope tracers, such as molybdenum (Mo), have been employed to further understand subduction zone fluid-rock interactions contributing to arc magmatic processes. The current hypothesis is that Mo is isotopically fractionated during dehydration of the subducting slab, leading to the retention of isotopically light Mo. The corresponding preferential movement of "heavy" Mo into fluids and melts can explain the high $\delta^{98}$ Mo values in several arcs.

The Schistes Lustrés and nearby coesite-bearing Lago di Cignana metasedimentary rocks, located in the Western Alps, experienced high-P/T subduction zone metamorphism at blueschist to eclogite grades. The Schistes Lustrés complex was subducted to depths of $40-70 \mathrm{~km}$ and experienced only modest amounts of geochemical overprinting during exhumation. Its ultrahigh-pressure counterparts exposed at Lago di Cignana were subducted to depths analogous to volcanic arcs $(80-120 \mathrm{~km})$. This study investigates the chemical and mineralogical changes that occurred during high-P/T metamorphism across five wellcharacterized localities of the Alpine suite, building on the work by Cook-Kollars et al., 2014; (Chem/Geol. [1]). This includes characterization of Mo isotope behavior with increasing metamorphic grade and assessment of primary mineralogical phases hosting Mo. We present $\delta^{98}$ Mo values and Mo concentrations for 31 samples across five well-characterized units of the Schistes Lustrés and Lago di Cignana.

The samples analyzed across this blueschist to eclogite grade "traverse" exhibit a range of $\delta^{98}$ Mo values and concentrations. Current data reveal a negative correlation between $\delta^{98} \mathrm{Mo}$ and molybdenum concentration. Average Mo concentrations across grade show no initial trends, with average values ranging from 0.56 to $0.58 \mathrm{ppm}$ at the Fraiteve (lowest grade) and Finestre regions to $0.36,0.37$, and $0.27 \mathrm{ppm}$ at the Assietta, Albergian, and Cignana localities. Average $\delta^{98} \mathrm{Mo}$ values trend upwards with increasing grade for the initial three metamorphic grades (-1.03, -0.80 , and $-0.36 \%$ (NIST 2134) for the Fraiteve, Assietta, and Albergian localities), then drop markedly to averages of -1.25 and $-0.70 \%$ for the Finestre and Cignana areas (highest grades). Ongoing work seeks to determine whether the isotope variations are driven by metamorphism or reflect protolith heterogeneity.

[1] Cook-Kollars, J, Bebout, G.E., Collins, N.C., Angiboust, S., and Agard, P., 2014, Chemical geology 386, 31-48. 